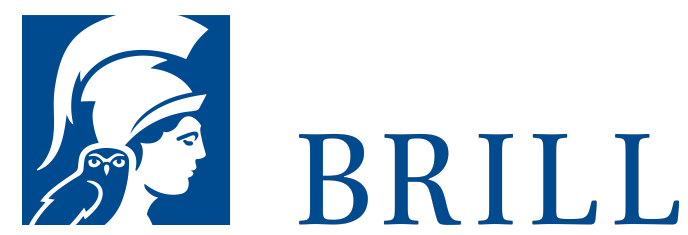

\title{
A Key to the Peshitta Gospels, Volume Two: Hē - Yōdh
}

\section{Author: Terry Falla}

This second volume of $A$ Key to the Peshitta Gospels again provides a range of information, previously unpublished, essential to the study of the Peshitta Gospel text as a translation of the Greek and as a literary work in its own right. It is designed to serve both scholar and student.

The Key, in which each word is classified according to its Syriac root, provides a) a Syriac-English dictionary, b) the notation of the part of speech for each Syriac term, c) referenced contextual phrases in English that illustrate a word's meanings, d) Syriac words of similar meaning, e) the corresponding Greek term for each Syriac term, f) a complete analytical concordance, g) an alphabetical index of Syriac catchwords, h) an index of Syriac verbal and nominal forms, i) an English index, j) an index of grammatical and general information.

The Key can be used as a lexicon, concordance, thesaurus, critical guide to Syriac-Greek correspondences, or resource for the critical investigation of the Syriac text of the Peshitta Gospels..

\section{Readership}

Students and scholars of Semitic Languages, of the New Testament and of Syriac language and literature. 
For more information see brill.com

Order information: Order online at brill.com +44330 333 0049 | customerservices@brill.com Submission information: brill.com/authors

Titles published by Brill | Fink, Brill | mentis or Brill | Schöningh: +49(o)715413279216| brill@brocom.de 